\title{
加振実験に基づくロッキング振動特性と非線形性を考慮したその数值解析
}

\author{
宮田 昌明*1，栗田 勝実*2，青木 繁*2
}

\section{Characteristics of rocking vibration based on excitation experiment and numerical analysis of it considering nonlinear effects}

\author{
Masaaki MIYATA $^{* 1}$, Katsumi KURITA ${ }^{* 2}$ and Shigeru AOKI ${ }^{* 2}$ \\ ${ }^{*}$ Advanced Course, Tokyo Metropolitan College of Industrial Technology \\ 1-10-40 Higashi-Oi, Shinagawa-ku, Tokyo 140-0011, Japan \\ ${ }^{* 2}$ Tokyo Metropolitan College of Industrial Technology \\ 1-10-40 Higashi-Oi, Shinagawa-ku, Tokyo 140-0011, Japan
}

Received: 11 December 2019; Revised: 6 April 2020; Accepted: 9 July 2020

\begin{abstract}
It is important to understand characteristics of rocking vibration related to overturning small structures inside buildings. In order to understand the overturning of the structure due to rocking vibration by numerical analysis, numerical analysis considering energy loss in a collision and duration of collision is performed by using a quadrilateral hysteresis loop characteristics in which repulsive force is a function of speed. In case that the restitution coefficient is constant and sine wave is used as an input wave, it is good agreement between experiment and numerical analysis response waveforms of rocking vibration in stationary process. However, it is not good agreement in nonstationary process. And it is not good agreement between experiment and numerical analysis response waveforms of rocking vibration using seismic ground motion as an input wave. On the other hand, in case that the restitution coefficient is considering energy loss in a collision and duration of collision, sine wave is used as an input wave, it is good agreement between experiment and numerical analysis response waveforms of rocking vibration in nonstationary process. Also it is good agreement using seismic ground motion as an input wave. From these results, numerical analysis for rocking vibration considering energy loss in a collision and duration of collision is effective using a quadrilateral hysteresis loop characteristics in which repulsive force is a function of speed. And it is effective for this model to understand overturning behavior of small structures in earthquake.
\end{abstract}

Keywords : Rocking vibration, Nonlinear effects, Excitation experiment, Numerical analysis, Sine wave, Seismic ground motion

1. 緒言

日本は頻繁に地震が発生する国である。平成 7 年兵庫県南部地震，平成 16 年新潟県中越地震及び平成 28 年熊 本地震の被害から理解できるように，大地震が都市直下，または，その近傍で起きると，地震動により様々な被 害が生じる．建築構造物は，それ自体が破壊や倒壊に至らなくても，建物オフィス内にある家具，書籍棚などの 什器やコンピュータサーバが転倒し, 人的被害を引き起こす（翠川, 佐伯, 1995)。 また, 博物館・美術館では, 館内の展示物が転倒し，破損に至る（喜谷他，1996）という文化遺産喆失を招く恐れがある，そのため，これら の小型構造物の転倒挙動に密接に関係するロッキング振動の振動性状を知ることは非常に重要な問題である.

ロッキング振動の研究は古くて新しい問題であり, これまでに多くの研究者によって行われている (Ishiyama, 1982, 鄭, 鈴木，1996，2000, 安田他，2016)。例えば, Ishiyama は物体の転倒に必要な最低の加速度, 速度, 変 位の転倒条件式を提案し，さらに実地震波に適用できることを証明した，安田らは，摩擦が介在する 1 自由度・

No.19-00440 [DOI:10.1299/transjsme.19-00440], J-STAGE Advance Publication date : 17 July, 2020

本論文は，Dynamics and Design Conference 2019 講演論文集(2019), No.237の掲載内容に基づいた論文である.

*1 学生員, 東京都立産業技術高等専門学校 専攻科（广140-0011 東京都品川区東大井 1-10-40）

*2 正員, 東京都立産業技術高等専門学校

E-mail of corresponding author: katsumi@metro-cit.ac.jp 
2 自由度ロッキング系における応答解析により摩擦係数が転倒挙動に与える影響など，その基本特性を明らかに した. また, ロッキング振動の応答計算において, 反発係数はロッキング振動における唯一の減衰要素であり, 重要なパラメータである. その推定方法は, 実験と解析の比較により推定する方法 (崎山他, 2013) や, 衝突に よる速度及び角速度の変化量に対してエネルギー消耗率を適用する方法（Shenton and Jones，1991）などがある. 著者らはこれまでに，振動実験及び反発係数一定の応答計算により，ロッキング振動特性及び反発係数の影響に ついて検討し, 構造物の転倒は非定常応答時に生じること,また強制ロッキング振動における反発係数の影響は, 非定常応答時に大きく関わっていることを明らかにした（宮田他，2018）。これらを考慮すると，構造物の転倒挙 動を数值解析によって明らかにするためには, 非定常応答時のロッキング振動の把握が重要であるといえる. し かし，多くのこれまでのロッキング振動の応答解析では，前述の方法により反発係数が一定の条件で行われてい る. 一方で, 衝突反発現象の解析に関する研究では, 反発係数の衝突速度依存性を考慮した数值解析が行われて いる（前澤, 渡辺，1975, 本江他，1999, 呂他，2006）。前澤らは 1 自由度系の定常衝突振動において, 反発係数 が衝突速度によって変化することを指摘している（前澤，渡辺，1975）。このモデルは, 衝突によって生じる反発 力に履歴特性を考慮することによって, 衝突によるエネルギー吸収と衝突時間を同時に考慮することができる.

本論文では前述のことを考慮して，まず転倒しやすい直方体の供試体に正弦波及び実地震波を入力とする実験 によって, ロッキング振動及び転倒挙動の測定をした. 次に, 反発係数を一定と仮定した数值解析によって, 口 ッキング振動及び転倒挙動を求めた. さらに, 反発係数が衝突速度の関数となる四角形の履歴特性を導入した数 值解析を実施した，その結果，実験結果をほぼ再現することが可能であり，四角形の履歴特性を導入した数值解 析が妥当であることを示した.

\section{2. 振動実験}

\section{$2 \cdot 1$ 実験方法}

図 1 に本実験に使用した供試体を示寸. 供試体はアルミ製で厚さ $10 \mathrm{~mm}$ の中空直方体とし, 幅 $B=60 \mathrm{~mm}$, 高 さ $H=200 \mathrm{~mm}$, 質量 $m=2.6 \mathrm{~kg}$ である. 振動実験の概要を図 2 に示す. 振動台上にレーザー変位計 2 台を設置し, 供試体との距離 $d_{1}, d_{2}$ を計測する. 式(1)を用いてロッキングによる回転角度を算出する.

$$
\theta=\tan ^{-1}\left(\frac{d_{2}-d_{1}}{h}\right)
$$

測定にはレーザー変位計（オプテックス・エフエー CD-250NV）から出力される信号を，インターフェイス（共 和電業 PCD-330B-F）を通して $0.005 \mathrm{~s}$ 間隔で PC に記録する. 入力波は正弦波と実地震波を使用し，加振方向は 水平 1 方向とした実験を行う。なお，滑りの伴わないロッキング振動を発生させるために，土台部に非粘着性の 滑り止めスプレーを塗布し実験を行う。

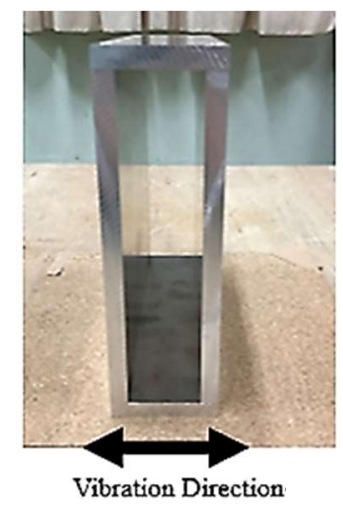

Fig. 1 Experimental specimen made by aluminum in this study.

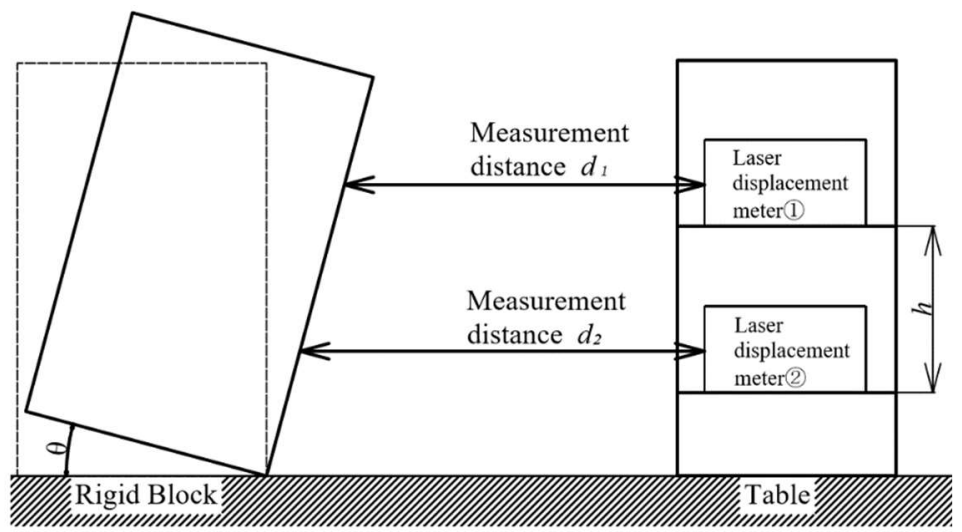

Fig. 2 Outline of measuring system. 


\section{$2 \cdot 2$ 正弦波を入力とした実験結果}

正弦波の振動数を $1 \mathrm{~Hz}$ から $5 \mathrm{~Hz}$ までを $1 \mathrm{~Hz}$ 刻みに, 加速度振幅を $200 \mathrm{Gal}$ から $600 \mathrm{Gal}$ まで $100 \mathrm{Gal}$ 刻みに変 化させながら実験を行う。その時の供試体の挙動を図 3 に示す。ここで，図中の○は，供試体がロッキングしな かった場合，、はロッキング振動した場合，×はロッキングまたは非定常なロッキング振動から転倒した場合を意 味する.これから，加振振動数が $3 \mathrm{~Hz}$ 以下では加速度振幅 $300 \mathrm{Gal}$ で供試体は転倒し，4 $\mathrm{Hz}$ 以上ではロッキング 振動が励起したことがわかる．加速度振幅 300 Gal は West の式（Milne，1881）から求められる静的転倒加速度 $294 \mathrm{Gal}$ に近い值である。このことから，4 Hz 以上の振動数において West の式から求められる值は，転倒加速度 としては不十分だが，ロッキングの開始条件としては十分と考えられる.

図 4 にロッキング振動が励起した実験の一例として加速度振幅 $400 \mathrm{Gal}$, 加振振動数 $4 \mathrm{~Hz}$ の結果を示す. 実験 装置の性能上，目標の加速度振幅に達するまでに立ち上がり時間が生じるため，加振開始 $20 \mathrm{~s}$ 後からの波形を示 す. 静的転倒加速度を超えるところで供試体の挙動がロッキング振動を励起しはじめていることが入力波形と応 答波形の比較から確認出来る. 供試体のロッキング振動は, 回転角度の振幅が変化する非定常な応答から, 回転 角度の振幅が約 4.1 ○゙一定な定常応答へ収束する. また, 供試体の転倒は非定常応答時に生じることを確認した.

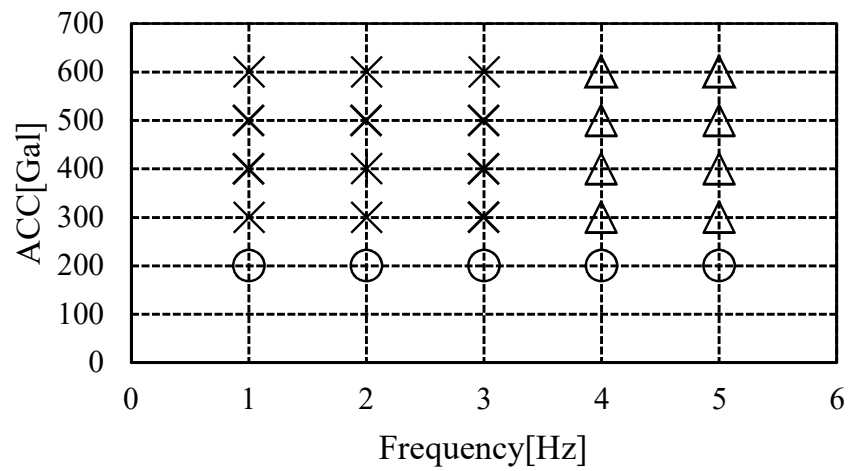

Fig. 3 Behavior of specimen by forced rocking vibration experiment. The symbols of $\bigcirc, \triangle, \times$ mean no rocking, rocking, and overturning, respectively.

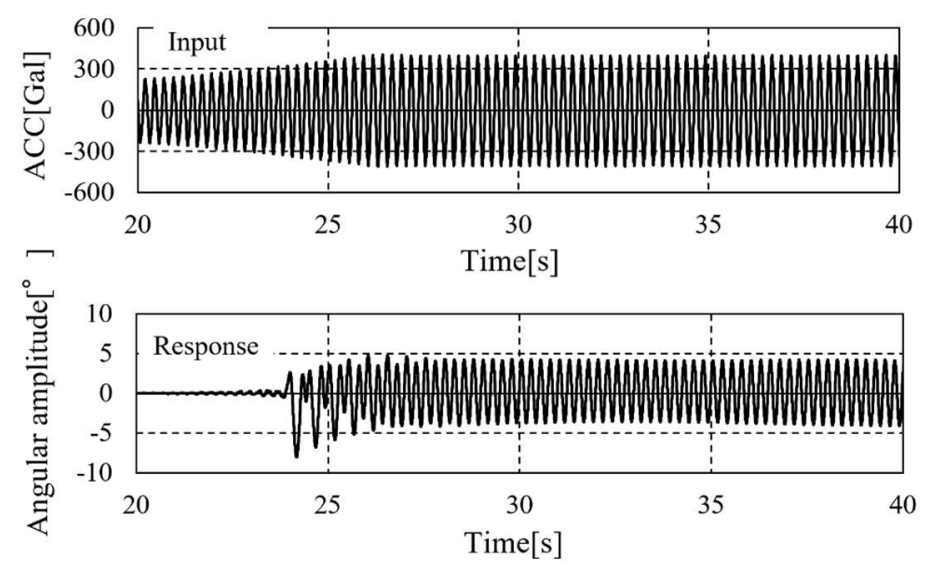

Fig. 4 Input and response waveforms by forced rocking vibration experiment using sine wave with the frequency of $4 \mathrm{~Hz}$ and the peak amplitude of $400 \mathrm{Gal}$ as input wave. The upper figure shows the input waveform, and the lower one shows the response waveform.

\section{$2 \cdot 3$ 地震波を入力とした実験結果}

旧神戸海洋気象台で観測された平成 7 年兵庫県南部地震の NS 成分を，振幅レベル $55 \%$ に低減したものを入力 波とした時の入力及び応答波形を図 $5(\mathrm{a})$ に示す. 入力波形の $5.6 \mathrm{~s}$ 及び $6.7 \mathrm{~s}$ に見られる $300 \mathrm{Gal}$ を超える加速度振 幅に対して, 応答波形では供試体が非定常なロッキング振動を示している。そして, $9.0 \mathrm{~s}$ 付近で転倒に至った。 供試体が非定常なロッキング振動から転倒を示したのは，入力の加速度振幅が $300 \mathrm{Gal}$ を超えた直後である. 
また，K-NET NIG019 小千谷（防災科研，2019）で観測された平成 16 年新潟県中越地震の EW 成分を，振幅レ ベル $40 \%$ に低減したものを入力波とした場合の入力及び応答波形を図 5(b)に示す. 前述と同様，加速度振幅が $300 \mathrm{Gal}$ を超えた直後に, 供試体の挙動が非定常なロッキング振動から転倒に変化している.この加速度振幅は供 試体の静的転倒加速度 $294 \mathrm{Gal}$ に近い值となっている. これらから West の式から求まる值は, 地震波に対しても 転倒加速度值としては不十分だが，ロッキング開始のしきい值として使用することが可能であることを示してい る.
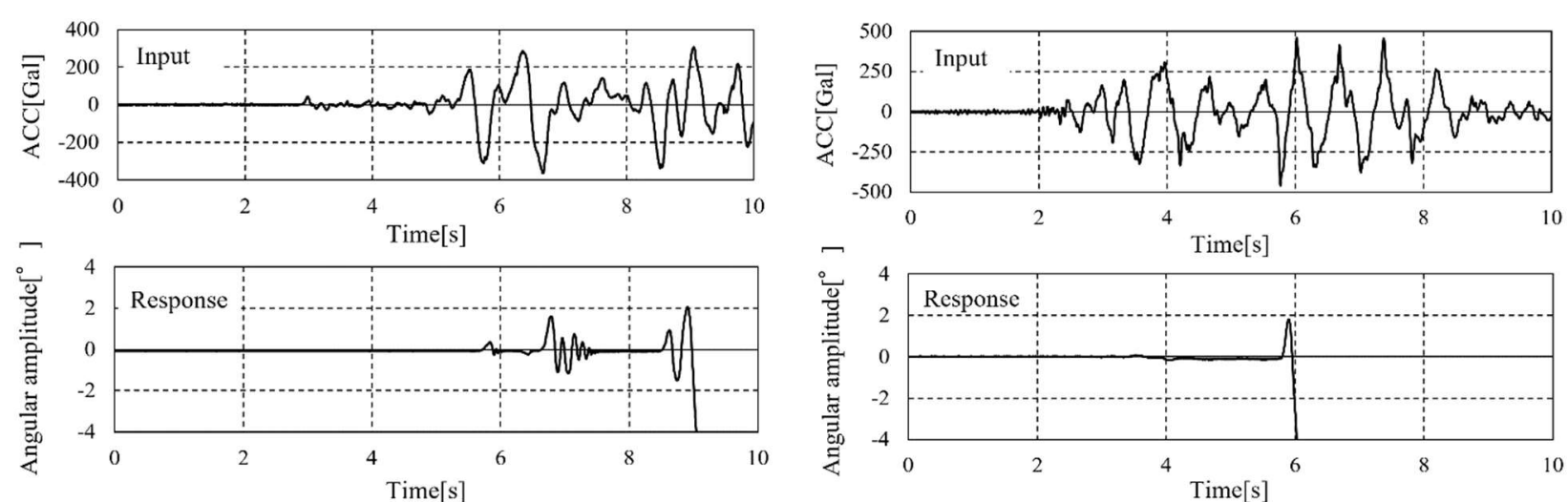

(a) JMA-KOBE (55\% scale)

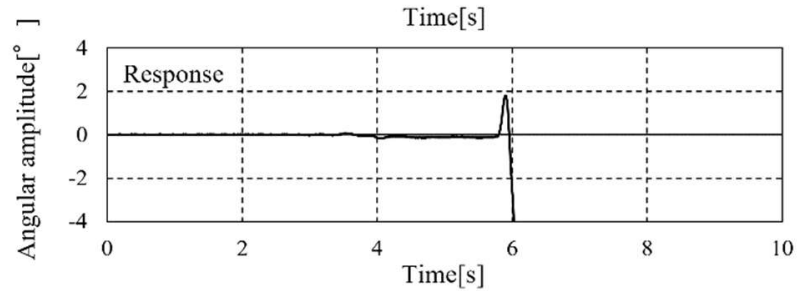

(b) K-NET NIG019 OJIYA (40\% scale)

Fig. 5 Input and response waveforms by vibration experiment using observed seismic ground motion as input wave. The left side shows the result of input wave using the 1995 Southern Hyogo Prefecture Earthquake observed at Kobe marine observatory scaled in $55 \%$. The right side is the result of input wave using the Mid Niigata Prefecture Earthquake in 2004 observed at Ojiya scaled in $40 \%$.

\section{3. 解析方法}

\section{$3 \cdot 1$ 数値解析モデル}

数值解析モデルを図 6 に示す. 数值解析モデルは実験に使用した供試体と同様に奥行き一面が開口した中空直 方体とする．ここで， $h_{1} ， h_{2}$ はそれぞれブロックの外側と内側の高さ， $b_{1}, b_{2}$ はそれぞれブロックの外側と内側 の幅, $R_{1}, R_{2}$ はそれぞれブロックの重心 $G$ から外側及び内側の端点までの距離である. 表 1 に数值解析モデルの 諸元を示寸．なお，表中における $I_{o}$ は慣性モーメント， $\Phi$ は転倒限界角度である.

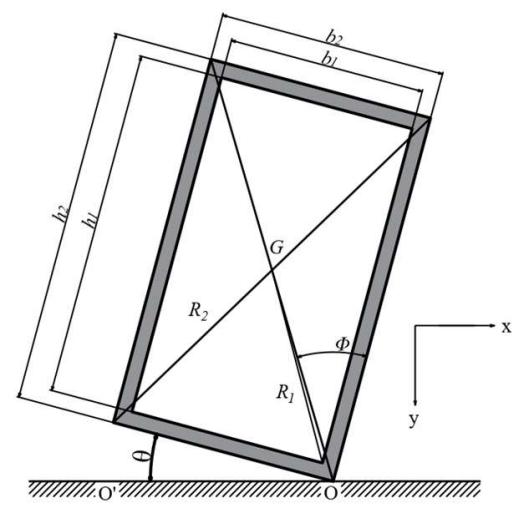

Table 1 Model dimension.

\begin{tabular}{|c|c|c|}
\hline Parameters & Value & Units \\
\hline$h_{2}$ & 200 & {$[\mathrm{~mm}]$} \\
\hline$h_{1}$ & 180 & {$[\mathrm{~mm}]$} \\
\hline$b_{2}$ & 60 & {$[\mathrm{~mm}]$} \\
\hline$b_{1}$ & 40 & {$[\mathrm{~mm}]$} \\
\hline$R_{2}$ & 104 & {$[\mathrm{~mm}]$} \\
\hline$R_{1}$ & 92.1 & {$[\mathrm{~mm}]$} \\
\hline$I_{o}$ & 15733 & {$\left[\mathrm{~g} \cdot \mathrm{mm}^{2}\right]$} \\
\hline$\Phi$ & 16.7 & {$[\mathrm{deg}]$} \\
\hline
\end{tabular}

Fig. 6 Numerical analysis model.

\section{$3 \cdot 2$ 運動方程式}

時刻 $t$ における入力の加速度振幅を $\ddot{u}_{x}(t)$ としたとき, 強制ロッキング振動の運動方程式は式(2)のように表せ る.

$$
I_{0} \ddot{\theta} \pm m g R_{2} \sin (\Phi \mp \theta)+m R_{2} \cos (\Phi \mp \theta) \cdot \ddot{u}_{x}(t)=0
$$


ここで， $\theta$ は構造物の回転角度， $g$ は重力加速度であり，上側の符号が $0^{\prime}$ 周り，下側の符号が0周りのロッキン グに対応する。また，構造物と土台部の衝突による角速度の変化は式(3)のように表せる.

$$
\dot{\theta}_{2}=e \dot{\theta}_{1}
$$

となる．ここで $e$ は反発係数， $\dot{\theta}_{1}, \dot{\theta}_{2}$ はそれぞれ衝突前後の角速度である.

この運動方程式にルンゲクッタ法を適用して応答計算をする。また，剛体ブロックがロッキングするときの条 件を式(4)に示す。この式は静的な転倒基準として知られている Westの式（Milne，1881）である.

$$
\ddot{u}>\frac{B}{H} \cdot g
$$

\section{$3 \cdot 3$ 構造物と土台部の衝突}

構造物と土台部の衝突は，ロッキング振動における唯一の減衰要素であり重要なパラメータである. 本研究に おける数值解析では前澤・渡辺のモデル（前澤，渡辺，1975）を適用する. 図 7 に示す四角形の履歴特性をもつ ものとすると, 反発係数 $e$ は次式のように表される.

$$
\begin{aligned}
& e=\dot{\theta}_{2} / \dot{\theta}_{1}=1.0, \quad \dot{\theta}_{1} \leq \dot{\dot{\theta}} \\
& e=\dot{\theta}_{2} / \dot{\theta}_{1}=\sqrt{K_{2} / K_{3}+\left(1-K_{2} / K_{1}\right)\left(K_{1} / K_{3}\right)\left(\dot{\dot{\theta}} / \dot{\theta}_{1}\right)^{2}}, \dot{\theta}_{1}>\dot{\theta}
\end{aligned}
$$

ここで， $K_{1}, K_{2}, K_{3}$ はそれぞれ変形量に対する反発力特性の傾斜を示す.また $\dot{\theta}_{1}, \dot{\theta}_{2}$ はそれぞれ衝突前後の角速 度, $\dot{\theta}$ は完全弾性衝突と非完全弾性衝突の境界となる速度であり, 次式で与えられる.

$$
\overline{\dot{\theta}}=\theta_{0} \sqrt{K_{1} / m}
$$

なお， $\theta_{0}$ は弾性限度の角変位である。弾性限度の角変位は，アルミ製高さ $200 \mathrm{~mm}$ の中実直方体の弾性限度の 変形量とし, フックの法則を用いて $\theta_{0}=0.27 \mathrm{rad}$ 決定した. 反発係数と衝突速度の関係を図 8 に示す. 反発 係数の非線形性を考慮した数值解析では，反発係数が図 8 に示すように衝突速度に依存して変化する場合につい て，強制ロッキング振動の数值解析を行う.

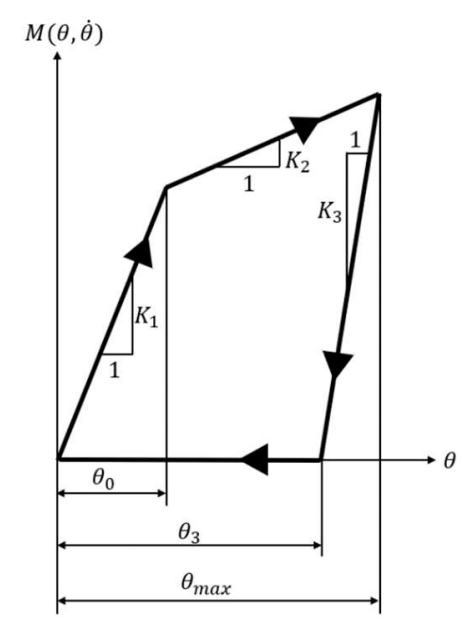

Fig. 7 Quadrilateral hysteresis loop characteristic. 


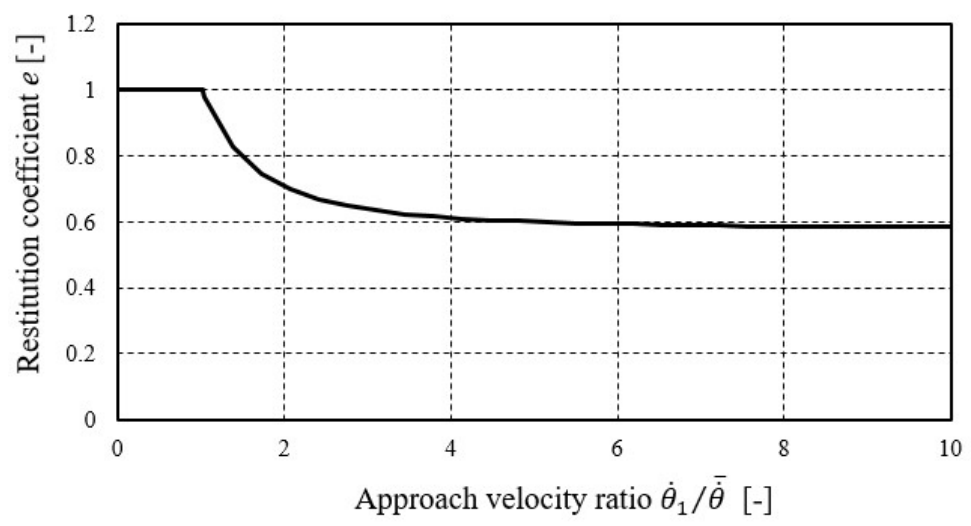

Fig. 8 Relationship between the restitution coefficient and the approach velocity ratio using the quadrilateral hysteresis loop characteristic shown in Fig. $7\left(K_{1}=3.0 \mathrm{Nm} / \mathrm{rad}, K_{2}=1.0 \mathrm{Nm} / \mathrm{rad}, K_{3}=3.0 \mathrm{Nm} / \mathrm{rad}\right)$.

\section{4. 反発係数を一定と仮定した数值解析}

ロッキング振動に関する既往の研究では，反発係数を一定と仮定した数值解析が行われている. そこで本章で は, 衝突による速度及び角速度の変化量に対しエネルギー消耗率を適用する方法 (Shenton and Jones, 1991) 及び, 実験と解析の比較により推定する方法（崎山他，2013）により決定した反発係数を用いて，反発係数一定と仮定 した数值解析を行い, 数值解析モデルの妥当性を検討する.

\section{$4 \cdot 1$ 正弦波を入カとした数值解析結果}

図 9 に加速度振幅 $400 \mathrm{Gal}$, 加振振動数 $4 \mathrm{~Hz}$ の正弦波を入力とした数值解析の結果を示す. 図 9(a)に示すのは, 衝突による速度及び角速度の変化量に対しエネルギー消耗率を適用する方法を基に推定した反発係数 $e=0.88$ を 用いた場合の結果である. 図 4 に示す実験結果と同様に，回転角度の振幅が変化する非定常過程のロッキング振 動から，回転角度の振幅が一定な定常応答へ収束している，定常応答は実験結果とほとんど一致しているが，転 倒挙動と密接に関係する非定常過程の波形性状は，実験結果と一致していない，また，図 9(b)に示すのは，自由 ロッキング振動実験と, その解析結果を基に推定した反発係数 $e=0.93$ を用いた場合の結果である. 実験結果と は異なり，1 $\mathrm{s}$ 付近で転倒に至っている.

これらのことから，衝突時の反発係数を一定と仮定した数值解析では，非定常時のロッキング振動の再現性が 得られないことが明らかになった。構造物の転倒は，非定常応答時に生じるため（宮田他，2018），その再現は 重要である. したがって, 解析に考慮するパラメータを検討する必要がある.

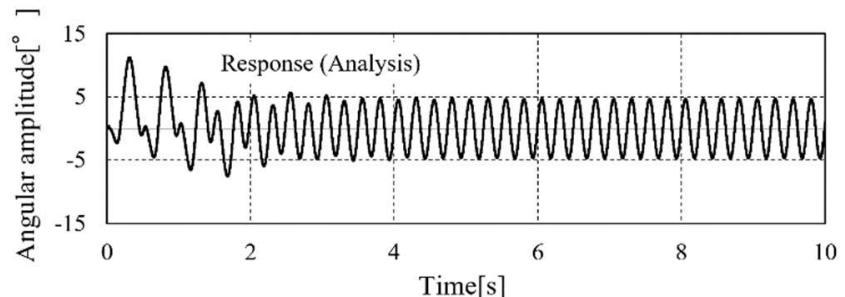

(a) $e=0.88$

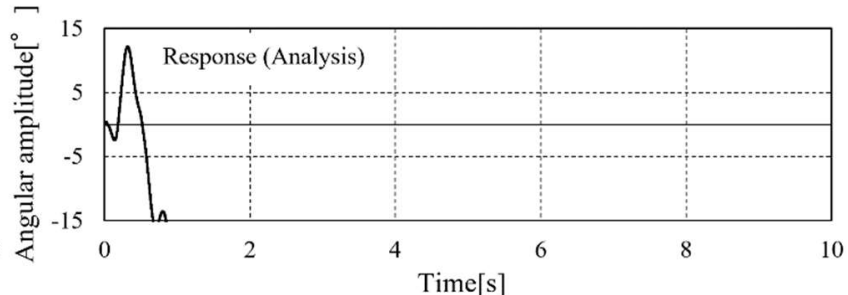

(b) $e=0.93$

Fig. 9 Response waveforms by numerical analysis using sine wave with the frequency of $4 \mathrm{~Hz}$ and the peak amplitude of 400 $\mathrm{Gal}$ as input wave. The left and right side show the results of constant restitution coefficient $e=0.88, e=0.93$, respectively.

\section{$4 \cdot 2$ 地震波を入カとした数值解析結果}

図 10 に旧神戸海洋気象台で観測された平成 7 年兵庫県南部地震の NS 成分を，振幅レベル $55 \%$ に低減したも のを入力とした場合の入力波形と応答波形を示す. 図 10(a)は，反発係数 $e=0.88$ を用いた場合の結果である. 入 力の加速度振幅が静的転倒加速度を超えた直後に転倒を示している．この結果は図 5(a)に示す実験結果と一致し 
ていない. また，図 10(b)に示寸，反発係数 $e=0.93$ を用いた場合の結果も同様に，実験結果と一致しない挙動を 示している.

このことから，反発係数を一定と仮定した数值解析では，地震動を入力とした構造物のロッキング振動及び転 倒挙動の再現性が得られないことが明らかになった．したがって，解析に考慮するパラメータを検討する必要が ある.
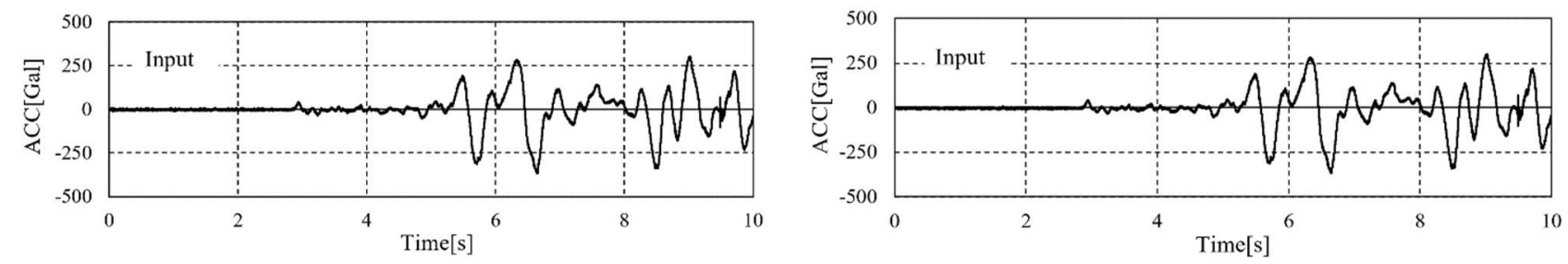

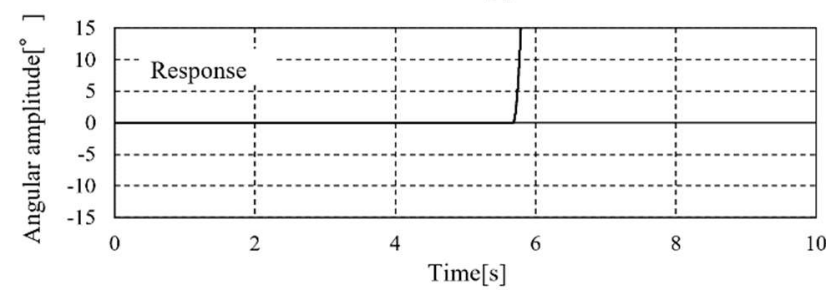

(a) $e=0.88, \quad \operatorname{MMA}-\operatorname{KOBE}(55 \%$ scale $)$

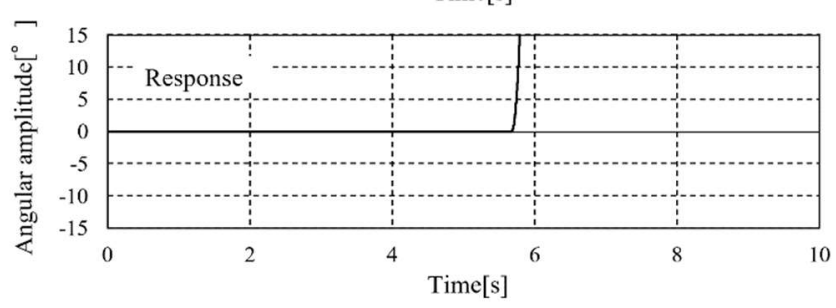

(b) $e=0.93$, JMA-KOBE $(55 \%$ scale $)$

Fig. 10 Input and response waveforms by numerical analysis using observed seismic ground motion as input wave. The input is the 1995 Southern Hyogo Prefecture Earthquake observed at Kobe marine observatory scaled in $55 \%$. The left and right side show the results of constant restitution coefficient $e=0.88, e=0.93$, respectively.

\section{5. 反発係数の非線形性を考慮した数值解析}

実験で使用した供試体に代表される構造物の転倒挙動を把握するうえで, 非定常時のロッキング振動を数值解 析で再現することは，前述の如く，地震時における構造物の転倒再現など地震防災に応用可能であることから非 常に重要である.しかし，衝突時の反発係数を一定と仮定した数值解析では，非定常時のロッキング振動の再現 性が得られないことが明らかになっている，したがって，解析に考慮するパラメータを検討する必要がある．こ こでは反発係数に非線形性を導入した数值解析を行う.

\section{$5 \cdot 1$ パラメータの同定と数値解析モデルの妥当性}

図 7 に示寸前澤・渡辺のモデルを用いる場合, 四角形履歷特性を表すパラメータ $K_{1}, K_{2}, K_{3}$ が必要となる. こ こでは，正弦波を入力とした実験で得られた応答波形に，数值解析で得られる応答波形をフォワードモデリング で合わせることで，最適な $K_{1}, K_{2}, K_{3}$ を決定する.

図 11 に実験結果と, $K_{1}=3.0 \mathrm{Nm} / \mathrm{rad}, K_{2}=2.1 \mathrm{Nm} / \mathrm{rad}, K_{3}=3.0 \mathrm{Nm} / \mathrm{rad}$ 場合における数值解析結果の応 答波形の比較を示す. 図 11(a)に示すのは加速度振幅 $400 \mathrm{Gal}$ ，加振振動数 $3 \mathrm{~Hz}$ における比較である. 実験によ る応答波形から，24 s で非定常なロッキング振動をし，25 s で転倒していることが読み取れる. 実験と解析結果 を比較すると両者の波形性状がほぼ一致している. 図 $11(\mathrm{~b})$ に示すのは加速度振幅 $400 \mathrm{Gal}$, 加振振動数 $4 \mathrm{~Hz}$ にお ける比較結果である. 実験における定常応答時の回転角度の振幅は $4.2^{\circ}$, 非定常応答時の最大回転角度が $8.0^{\circ}$ で ある. また, 解析における定常応答時の回転角度は $4.4^{\circ}$, 非定常応答時の回転角度が $8.0^{\circ}$ である. このことから, 実験と解析において定常応答時の振幅, 及び非定常応答時の最大回転角度がほとんど一致していることがわかる. また，波形性状もほとんど一致している．図 $11(\mathrm{c}) に ，$ 加速度振幅 $400 \mathrm{Gal}$ ，加振振動数 $5 \mathrm{~Hz}$ の結果を示寸.この 結果においても同様な傾向にあることがわかる.

これらから, 反発係数一定の数值解析では再現性が得られなかった非定常応答時の波形が, 衝突によるエネル ギー吸収及び衝突時間を考慮したモデルを適用することで再現性のある結果が得られた。ゆえに四角形履歴特性 を導入した数值解析モデルは妥当であるといえる. 

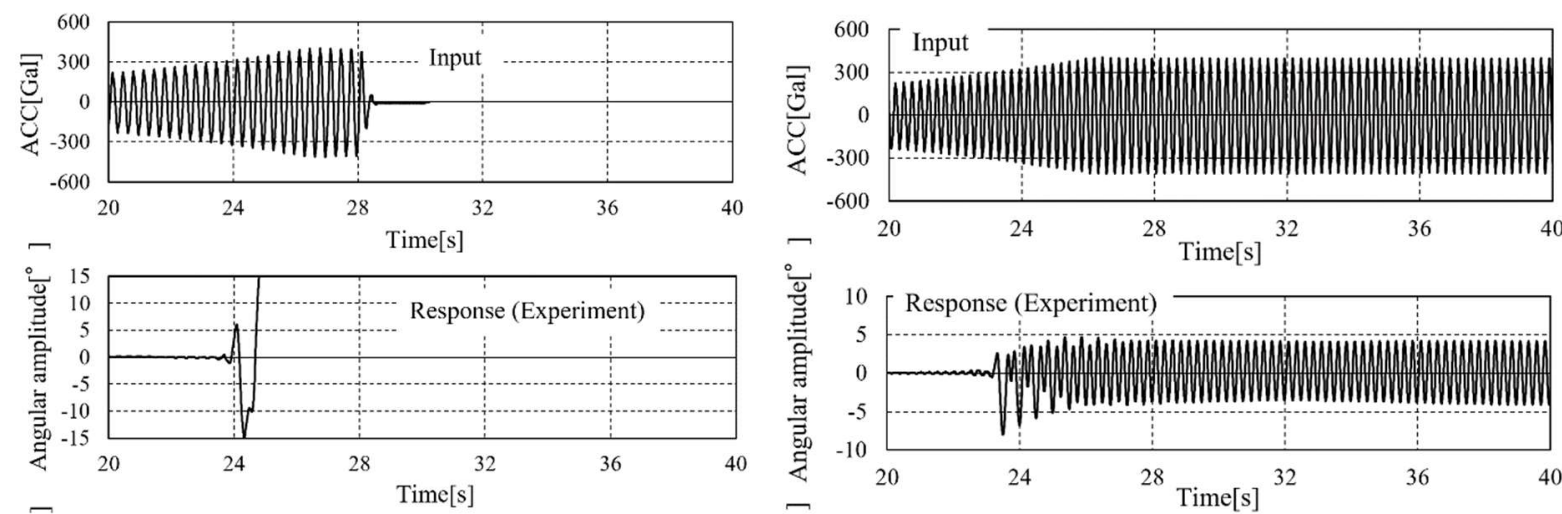

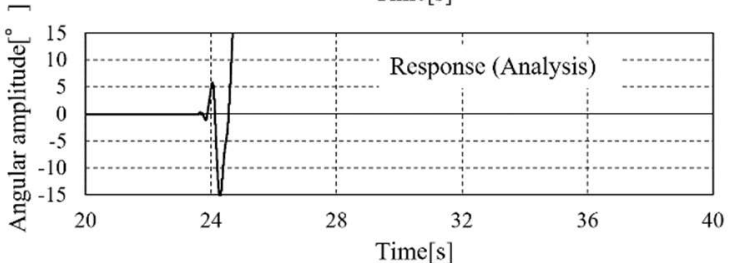

(a) $400 \mathrm{Gal}, 3 \mathrm{~Hz}$

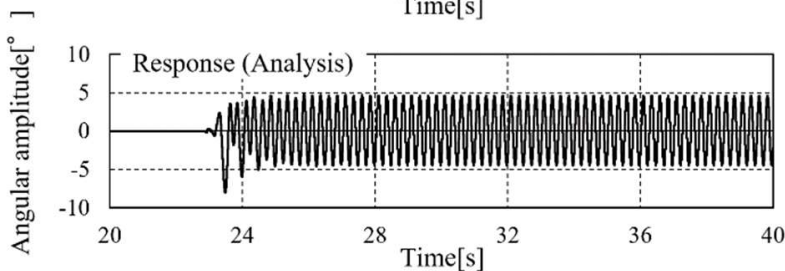

(b) $400 \mathrm{Gal}, 4 \mathrm{~Hz}$
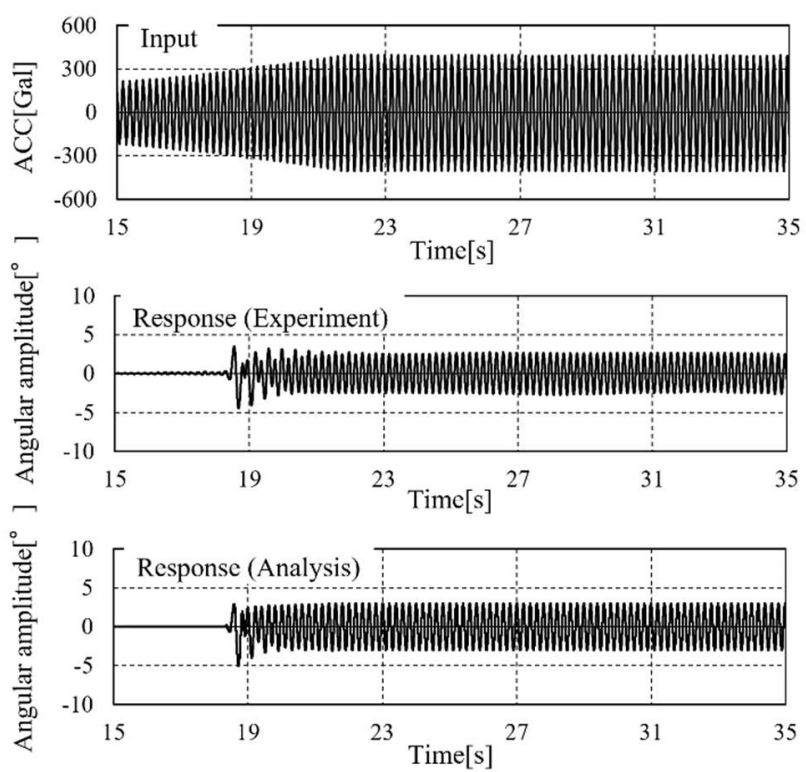

(c) $400 \mathrm{Gal}, 5 \mathrm{~Hz}$

Fig. 11 Comparison of results between the experiment and the numerical analysis response waveforms. (a): In case of sine wave with the frequency of $3 \mathrm{~Hz}$ and the peak amplitude of $400 \mathrm{Gal}$ as input wave. (b): In case of sine wave with the frequency of $4 \mathrm{~Hz}$ and the peak amplitude of $400 \mathrm{Gal}$. (c): In case of sine wave with the frequency of $5 \mathrm{~Hz}$ and the peak amplitude of $400 \mathrm{Gal}$.

\section{$5 \cdot 2$ 地震波を入力とした数值解析結果}

図 12 に地震波を入力とした場合の加振実験及び正弦波で得られた $K$ の值を用いて得られた数值解析による応 答波形を示す。図 12(a)は，旧神戸海洋気象台で観測された平成 7 年兵庫県南部地震の NS 成分を，振幅レベル $55 \%$ に低減したものを入力とした場合の入力波形と実験及び数值解析の応答波形である. 実験と同様に，5.6 $\mathrm{s}$ 及 び $6.7 \mathrm{~s}$ で非定常なロッキング振動をし， $8.5 \mathrm{~s}$ において転倒することが数值解析における応答波形からわかる. また，図 12(b)は，同一の地震波を振幅レベル $60 \%$ に低減したものを入力とした場合の入力波形と，実験及び解 析の応答波形である。同一の地震波でも振幅レベルを変化させると転倒に至る時刻が変化することがわかるが，

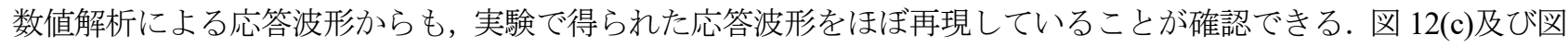
12(d)は，それぞれ K-NET NIG019 小千谷で観測された平成 16 年新潟県中越地震の EW 成分を，振幅レベル $40 \%$ 
及び $50 \%$ に低減したものを入力とした場合の入力波形と実験及び解析の応答波形である. 異なる地震波を用いた 場合にも, 図 12(a)及び図 12(b)の結果と同様に, 実験で得られた応答波形をほぼ再現していることが確認できる.

以上のことから，反発係数の非線形性を考慮した数值解析モデルを適用することにより，構造物のロッキング 振動及び転倒挙動を数值解析で再現出来ることがわかる.
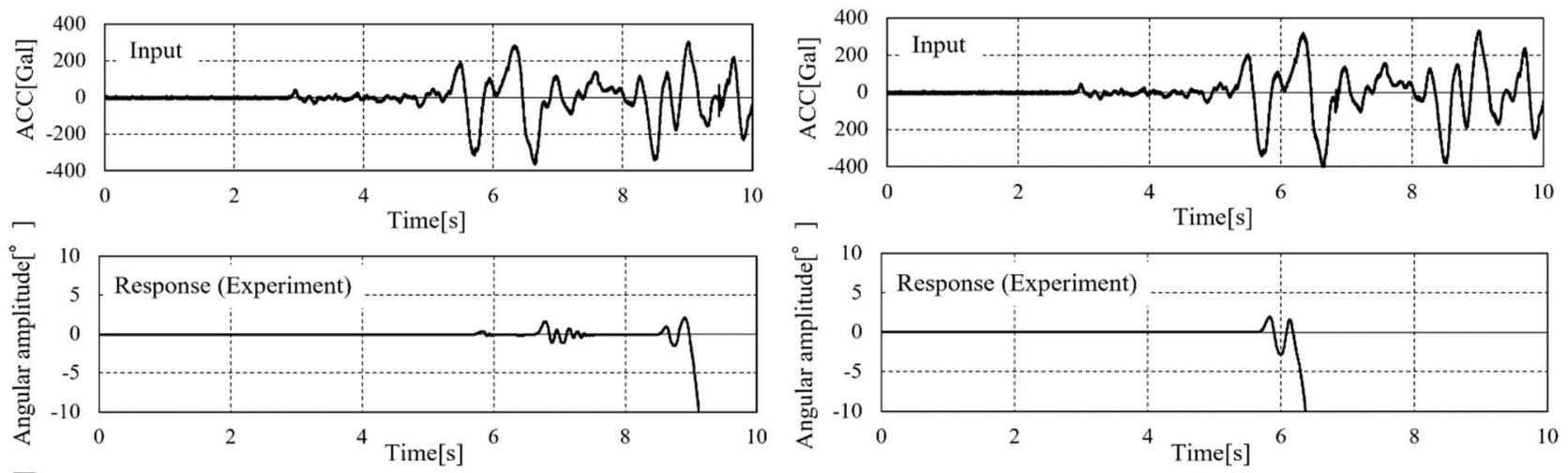

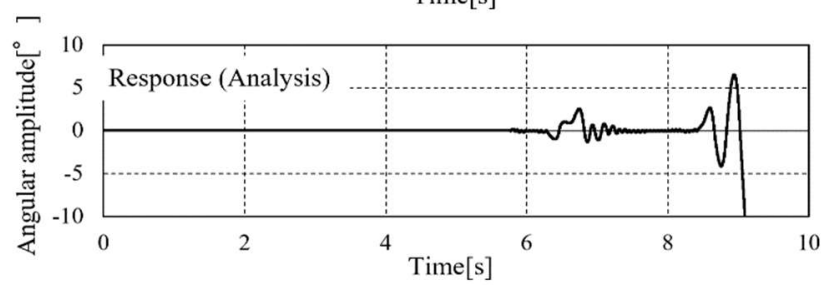

(a) JMA-KOBE (55\% scale)
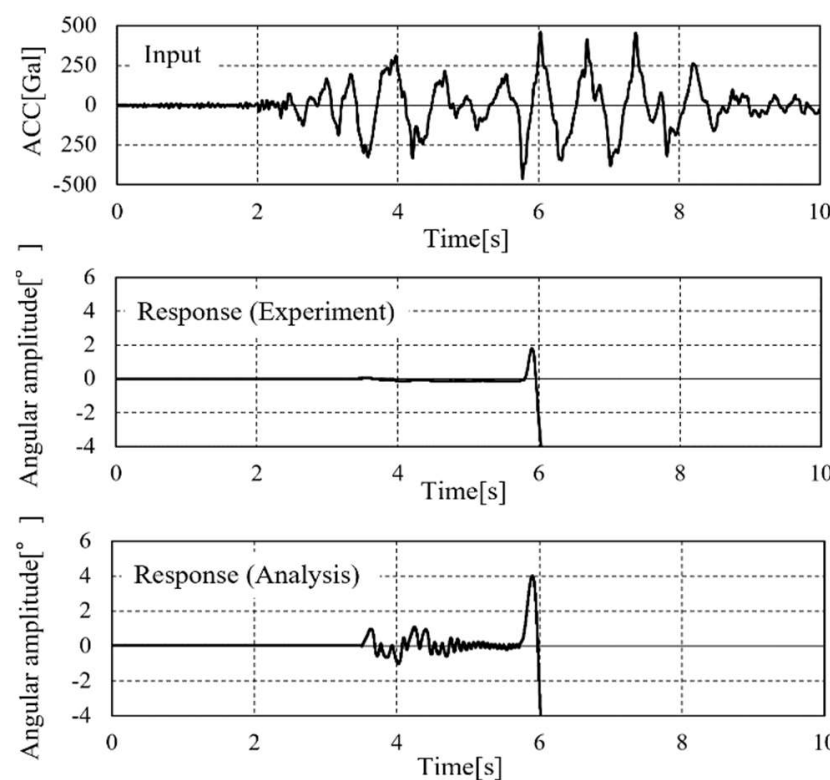

(c) K-NET NIG019 OJIYA (40 \% scale)

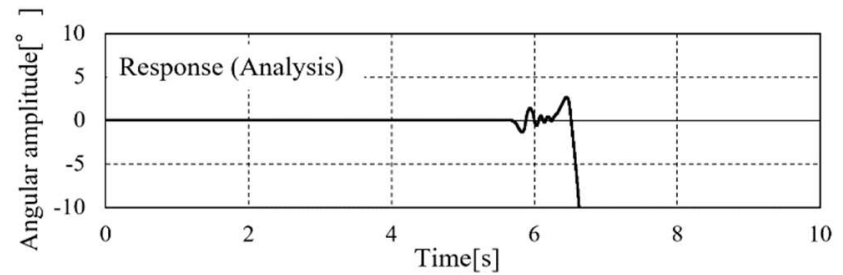

(b) JMA-KOBE (60\% scale)
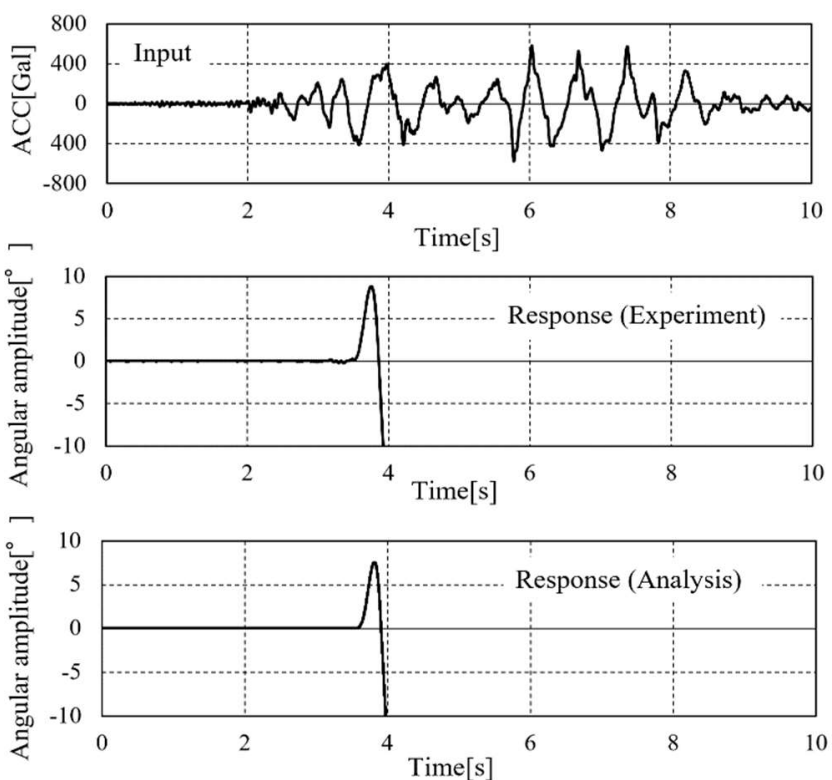

(d) K-NET NIG019 OJIYA (50 \% scale)

Fig. 12 Comparison of results between the experiment and the numerical analysis response waveforms using observed seismic ground motion as input wave. (a): In case of the 1995 Southern Hyogo Prefecture Earthquake observed at Kobe marine observatory as input wave (scale: 55 \%). (b): In case of the 1995 Southern Hyogo Prefecture Earthquake (scale: 60 \%). (c): In case of the Mid Niigata Prefecture Earthquake in 2004 observed at Ojiya (scale: $40 \%$ ). (d): In case of the Mid Niigata Prefecture Earthquake in 2004 (scale: $50 \%$ ). 


\section{6. 結 語}

本研究では，反発係数を一定と仮定した数值解析及び，反発係数の非線形性を考慮した数值解析を行い，実験 結果と比較することで，正弦波及び地震波を入力とした場合の構造物のロッキング振動及び転倒挙動に対する数 值解析モデルの有効性を示すことを目的として以下の結論を得た.

（1）供試体の応答が West の式で表される静的転倒加速度を超えることで, 構造物の挙動はロッキング振動及び 転倒に変化する.

（2）正弦波を入力として反発係数を一定と仮定した数值解析モデルによる解析の結果, 定常過程のロッキング 振動は実験結果と一致したが，構造物の転倒挙動が生じる非定常過程のロッキング振動は一致しなかった. また，地震波を入力とした場合，数值解析で得られた結果は実験結果と一致しない.

（3）正弦波を入力として衝突によるエネルギー吸収と衝突時間を考慮した数值解析モデルを用いた解析の結果， 構造物の転倒挙動が生じる非定常応答時の最大回転角度及び波形性状は，ほぼ一致した．また，地震波を入 力とした解析の結果は，加振実験で得られた結果をほぼ説明することができる.

以上のことから，構造物転倒の挙動を数值解析によって把握するためには，反発係数を一定と仮定した数值解 析モデルでは不十分であり, 反発係数の非線形性を考慮した数值解析モデルが有効であることを示した. また, これを用いた数值解析は，構造物の転倒挙動を把握する上で有効であることを示した.

\section{謝 辞}

本研究で使用した地震観測記録は，気象庁及び防災科学技術研究所で公開されているものを利用させていただ きました. また, 查読者からのコメントは, 本論文の改善に大変役立ちました. 記して感謝いたします. 本研究 は JSPS 科研費 17K01203 の助成を受けたものです.

\section{文献}

本江哲行, 佐藤秀紀, 岩田佳雄, 小松崎俊彦, 本郷陽子, 球と平面からなる衝突系のモデル化と解析, 日本機械学 会論文集 C 編, Vol.65, No.634 (1999), pp.2287-2293.

Ishiyama, Y., Criteria for overturning of bodies by earthquake excitations, Transactions of the Architectural Institute of Japan, No.317 (1982), pp.1-14.

鄭萬溶，鈴木浩平，剛体ブロック型構造物のロッキング振動に関する基礎的研究，日本機械学会論文集 $\mathrm{C}$ 編, Vol.62, No.603 (1996), pp.4139-4146.

鄭萬溶, 鈴木浩平，正弦波励振を受ける剛体ブロック構造物のロッキング振動特性，日本機械学会論文集 $\mathrm{C}$ 編, Vol.66, No.645 (2000), pp.1453-1461.

喜谷美宣, 森田稔, 勝盛典子, 塚原晃, 山中健, 阪神・淡路大震災による被害と復旧, 神戸市立博物館研究紀要, No.12 (1996), pp.17-48.

呂中杰, 田中皓一, 西田政弘, 権成文, 回転を伴う円板の衝突反発現象, 日本機械学会論文集 A 編, Vol.72, No.717 (2006), pp.787-793.

前澤成一郎, 渡辺武, 履歴特性を持つ物体の定常衝突振動の解析（第 2 報, 反発力が四角形の履歴特性をもつ場 合），日本機械学会論文集, Vol.41, No.352 (1975), pp.3458-3469.

翠川三郎, 佐伯玩磨, オフィスビル群における地震時の室内負傷者発生予測, 日本建築学会構造系論文集, No. 476 (1995), pp.49-56.

Milne, J., Experiments in observational seismology, Transactions of the Seismological Society of Japan, Vol.3 (1881), pp.1264.

宮田昌明, 栗田勝実, 青木繁, 構造物を対象とした自由振動と強制振動によるロッキング振動特性の基礎的検討,

Dynamics and Design Conference 2018 講演論文集 (2018), 219.

防災科研 K-NET, KiK-net（NIED K-NET, KiK-net）, available from <https://www.doi.org/10.17598/NIED.0004>, (参照 日 2019 年 1 月 10 日).

崎山佑樹, 松平和也, 小松崎俊彦, 岩田佳雄, 構造物の転倒性に関する基礎的検討, 日本機械学会 2013 年度年次 大会講演論文集 (2013), G101055.

Shenton, H.W. and Jones, N.P., Base excitation of rigid bodies. I: Formulation, Journal of Engineering Mechanics, Vol.117 
(1991), pp.2286-2306.

安田裕矢，渡邊鉄也，鞆田顕章，摩擦を考慮したロッキング振動，日本機械学会論文集, Vol.82, No.838 (2016), DOI:10.1299/transjsme.16-00061.

\section{References}

Hongo, T., Sato, H., Iwata, Y., Komatsuzaki, T. and Hongo, Y., Modeling and analysis of impact system composed of ball and plane, Transactions of the Japan Society of Mechanical Engineers, Series C, Vol.65, No.634 (1999), pp.2287-2293 (in Japanese).

Ishiyama, Y., Criteria for overturning of bodies by earthquake excitations, Transactions of the Architectural Institute of Japan, No.317 (1982), pp.1-14.

Jeong, M. and Suzuki, K., Basic study on the dynamic behavior of rocking rigid body structure, Transactions of the Japan Society of Mechanical Engineers, Series C, Vol.62, No.603 (1996), pp.4139-4146 (in Japanese).

Jeong, M. and Suzuki, K., A study on rocking vibration of rigid block structure subjected to sinusoidal excitation, Transactions of the Japan Society of Mechanical Engineers, Series C, Vol.66, No.645 (2000), pp.1453-1461 (in Japanese).

Kitani, Y., Morita, M., Katsumori, N., Tsukahara, A. and Yamanaka, K., From the hanshin awaji earthquake to the reopening progress report and damage report, Bulletin of Kobe City Museum, No.12 (1996), pp.17-48 (in Japanese).

Lu, Z., Tanaka, K., Nishida, M. and Quan, C., Impact and restitution of rotating circular plate, Transactions of the Japan Society of Mechanical Engineers, Series A, Vol.72, No.717 (2006), pp.787-793 (in Japanese).

Maezawa, S. and Watanabe, T., Analysis on steady state response of system with hysteresis loop characteristics $\left(2^{\text {nd }}\right.$ report, for system with restitution force having quadrilateral hysteresis loop characteristics), Transactions of the Japan Society of Mechanical Engineers, Vol.41, No.352 (1975), pp.3458-3469 (in Japanese).

Midorikawa, S. and Saeki, T., Evaluation of earthquake injuries in office buildings, Journal of Structural and Construction Engineering, Vol.60, No.476 (1995), pp.49-56 (in Japanese).

Milne, J., Experiments in observational seismology, Transactions of the Seismological Society of Japan, Vol.3 (1881), pp.1264.

Miyata, M., Kurita, K. and Aoki, S., Study on rocking vibration characteristics by free and forced vibration for structures, Dynamics \& Design Conference 2018 (2018), 219 (in Japanese).

National Research Institute for Earth Science and Disaster Resilience (2019), NIED K-NET, KiK-net, National Research Institute for Earth Science and Disaster Resilience, available from <https://www.doi.org/10.17598/NIED.0004>, (accessed on 10 January, 2019).

Sakiyama, Y., Matsudaira, K., Komatsuzaki, T. and Iwata, Y., Fundamental study on the falling of structures induced by base excitation, Proceedings of the Symposium on the Japan Society of Mechanical Engineers 2013 (2013), G101055 (in Japanese).

Shenton, H.W. and Jones, N.P., Base excitation of rigid bodies. I: Formulation, Journal of Engineering Mechanics, Vol.117 (1991), pp.2286-2306.

Yasuda, Y., Watanabe, T. and Tomoda, A., Rocking vibration with friction, Transactions of the JSME (in Japanese), Vol. 82, No.838 (2016), DOI:10.1299/transjsme.16-00061. 